\title{
Innovation in Business Groups
}

\author{
Sharon Belenzon \\ Fuqua School of Business, Duke University, Durham, North Carolina 27708, sb135@duke.edu \\ Tomer Berkovitz \\ Graduate School of Business, Columbia University, New York, New York 10027, tb2122@columbia.edu
}

\begin{abstract}
$\mathrm{U}$ sing novel data on European firms, this paper investigates the relationship between business groups and innovation. Controlling for various firm characteristics, we find that group affiliates are more innovative than standalones. We examine several hypotheses to explain this finding, focusing on group internal capital markets and knowledge spillovers. We find that group affiliation is particularly important for innovation in industries that rely more on external funding and in groups with more diversified capital sources, consistent with the internal capital markets hypothesis. Our results suggest that knowledge spillovers are not the main driver of innovation in business groups because firms affiliated with the same group do not have a common research focus and are unlikely to cite each other's patents.
\end{abstract}

Key words: business groups; innovation; patents; internal capital markets; knowledge spillovers

History: Received August 12, 2008; accepted August 26, 2009, by Scott Shane, entrepreneurship. Published online in Articles in Advance February 12, 2010.

\section{Introduction}

The relation between organizational form and corporate innovation has been extensively debated among academics and policy makers. Business groups, organizations that include several legally independent firms, are a common ownership structure in many countries outside the United States. While the empirical literature has focused mostly on the role of business groups in replacing imperfect or missing markets in developing countries (e.g., Khanna and Rivkin 2001, Mahmood and Mitchell 2004, Chang et al. 2006), very little is known about the role of business groups in facilitating innovation in developed and research and development (R\&D)-intensive economies. In this paper, we explore the relationship between business groups and innovation using a novel and comprehensive data set on patents, ownership, and financials for European firms.

There are several reasons to expect business groups to foster innovation. First, business groups tend to be large and well diversified. Deep pockets, economies of scale and scope, and cost spreading are some of the reasons thought to facilitate the innovative efforts of big organizations (Cohen and Levin 1989, Cohen and Klepper 1996). In particular, diversification can allow business groups to better insure themselves against the uncertainties associated with the R\&D process (Nelson 1959, Khanna and Yafeh 2007). Recent evidence for the United States suggests that diversified corporations are better positioned to internally finance new investment opportunities, especially when cash flows and investment opportunities are less correlated across divisions (Duchin 2010). Second, the group internal capital can be more favorable for funding and governing innovation than outside capital. In a world with asymmetric information, external financing is presumably more costly than internal financing (Myers and Majluf 1984, Greenwald et al. 1984). If asymmetric information is mitigated within groups, an innovative affiliate can gain access to more capital than a standalone firm and at a lower cost (Himmelberg and Petersen 1994, Stein 1997). Third, affiliated firms can benefit from knowledge spillovers from the research of other firms in the same group. Since the seminal studies by Griliches (1979) and Scherer (1982), an expanding literature has documented the positive effect of knowledge spillovers on innovation. Internal labor and technology markets are likely to play an important role in facilitating knowledge sharing between group members and by that lead to more rapid innovation.

There are several reasons, however, to suspect that small specialized firms, such as venture capital (VC)-backed standalones, are more conducive to innovation. Large bureaucratic organizations can stifle creativity and even deliberately delay the development of new technologies to avoid cannibalizing the streams of rents from existing ones (Arrow 1962, Reinganum 1983). Also, evidence on American conglomerates suggests that internal capital markets and frequent reallocation of funds across divisions are prone to agency problems that can lead to biased decision making, less risk taking, and weak commitment 
to long-term profitable projects (Teece 1996, Hitt et al. 1996, Seru 2006). These agency problems are likely to be mitigated, if not completely muted, in VC-backed standalones that typically benefit from strong governance in the form of tight monitoring and highpowered incentives.

In light of these divergent theoretical predictions and empirical findings, we make three key contributions: (i) using novel comprehensive data on ownership ties and patents, we map the ownership structure and innovation of European firms; (ii) we establish a positive relation between group affiliation and corporate innovation; and (iii) we test several hypotheses to explain how business groups may facilitate innovation.

Business-group affiliation is endogenous and might be affected by unobserved firm characteristics. More specifically, if groups can identify standalone firms with higher expected success probability, they may engage in "winner picking." We mitigate the potential group selection bias in four ways. First, our ownership structure is stable over the estimation period 1995-2004. We merge our ownership data with a database on mergers and acquisitions and exclude firms that experience a change in their affiliation status, pushing back the potential endogeneity problem to the beginning of the sample. Second, we alleviate the effect of unobserved heterogeneity in firm-level innovation quality at the beginning of our sample by controlling for the pre-sample average number of patents of each firm (Blundell et al. 1999). Third, we mitigate the selection problem by examining specifications with only affiliated firms. Fourth, we investigate several hypotheses that are unlikely to be explained solely by "winner picking."

Our analysis is based on three data sets on private and publicly traded European firms. To determine business-group affiliation and compile measures of group characteristics, we develop an algorithm that constructs the complete structure of groups from data on almost one million ownership links. To measure innovation, we match all granted patent applications from the European Patent Office (EPO) and the United States Patent and Trademark Office (USPTO) to all European firms. We use current and historical versions of the Amadeus accounting database to assemble a comprehensive panel data of firm characteristics.

Using our newly assembled data set, we investigate whether affiliates patent more than standalones. Our findings point toward a positive relation between business groups and innovation. Patents are disproportionately concentrated in business groups relative to number of firms and assets. Whereas in our full sample $22 \%$ and $55 \%$ of firms and assets, respectively, are controlled by business groups, $74 \%$ of patents are assigned to group affiliates. Also, business groups appear to be more prevalent in the most R\&Dintensive industries. This is again consistent with the view that the group structure fosters R\&D activity. Controlling for various firm characteristics, we find supporting evidence that affiliates generate substantially more patents than standalones. We proceed to examine several hypotheses that may explain this result. We focus mostly on group internal capital markets and knowledge spillovers between group members. Business groups in our sample tend to operate in more than one country, and a substantial fraction of groups are family owned. Thus, we also relate our findings to the literature on multinational organizations and family-owned firms.

Our test of the internal capital markets hypothesis is twofold. We start by examining whether the group-innovation relation is stronger in industries that depend more on external financing (Rajan and Zingales 1998). Subsequently, we study the relation between group diversification and innovation because lower correlation between the cash flows and investment opportunities of the group affiliates is expected to enhance the benefit of the internal capital market. Our results are consistent with the internal capital markets hypothesis. First, if business-group affiliation is important for funding innovation, we expect more firms to be affiliated with groups in industries that have a stronger reliance on external financing. Using a sample that covers virtually all significant firms in the economy (approximately 500,000 firms), this prediction is confirmed. We find that firms are more likely to be affiliated with business groups as their demand for external finance rises and also that the effect of group affiliation on innovation is stronger in the high-external-dependence industries. Second, consistent with the diversification hypothesis, we find that, controlling for group size, groups that have more diversified capital sources tend to be more innovative than specialized ones.

We continue to explore the relation between group affiliation and innovation by investigating the knowledge spillovers hypothesis. We start by looking at the research focus of different affiliates in the same group. According to the knowledge spillovers hypothesis, we expect firms in the same group to have related R\&D programs. We follow Jaffe (1986) and compute a measure of technological similarity between firm pairs based on the overlap in technology fields specified in their patents. Next we explore the pattern of citations made by group affiliates. If knowledge sharing is important for group innovation, we expect frequent within-group citations. Both tests are inconsistent with the knowledge spillovers hypothesis: we find that affiliated firms in the same group tend to operate in unrelated technology areas and have a very 
low frequency of within-group citations (on average, only $1 \%$ of the citations made by group affiliates are to patents by other affiliates of the same group).

Approximately one-quarter of business groups in our sample have affiliates from at least two different countries. Affiliation with a multinational organization can enhance innovation in several ways. For example, Bloom et al. (2007) show that firms affiliated with multinational organizations are more likely to invest in "soft" innovation such as information communication technologies. Affiliation with a multinational organization can also facilitate innovation by enhancing access to foreign technologies (Griffith et al. 2006, Khanna and Palepu 1999). Indeed, we find that diversification across countries is positively correlated with innovation.

Last, almost $30 \%$ of the groups in our sample are family held. Family ownership may have adverse effects on innovative activity. On one hand, a family CEO may focus more on the long-term compared with an unrelated executive (Cadbury 2000). This may imply that family firms invest more in $R \& D$. However, a family CEO may have less expertise in innovation compared with a professional CEO. Our evidence suggests a negative relation between family ownership and group innovation.

The remainder of this paper is organized as follows: $\$ 2$ presents the data, $\$ 3$ describes the econometric specifications, $\S 4$ reports the estimation results, and $\S 5$ concludes.

\section{Data}

This paper combines data from several sources: (i) ownership data on business groups from Amadeus (a database published by Bureau van Dijk Electronic Publishing (BvDEP)), (ii) information on patents and citations from the EPO and USPTO, and (iii) accounting data from Amadeus and Compustat.

(i) Business groups. We define a business group as an organization that includes at least two legally independent firms. To fully characterize groups, we determine group affiliation for all firms in the Amadeus database. To ensure that all ownership links represent control, we make the following assumptions: for private subsidiaries we keep only links where the shareholder has at least $50 \%$ of the voting rights, and for public firms we keep only links where the shareholder has at least $20 \%$ of the voting rights. ${ }^{1}$ These

\footnotetext{
${ }^{1}$ For reasons of conservatism, we define control of a private firm as owning more than $50 \%$ of the firm's voting rights (excluding nonvoting shares). Following previous literature on public firms (La Porta et al. 1999, Faccio and Lang 2002, and others), which have a more dispersed ownership, we set the threshold for public firms at $20 \%$. All of the results of this paper are robust to different plausible specifications of these thresholds.
}

two assumptions leave us with almost one million ownership links. To infer group structure from these links, we develop an algorithm that constructs corporate control chains and then groups firms controlled by the same ultimate owner. Appendix A.1 provides details about the ownership algorithm.

(ii) Patents. To create a firm-level measure of innovation, we examine patent-based indicators of technological advances by firms. ${ }^{2}$ We construct a novel database of European firm patents by matching all granted patent applications from the USPTO and EPO to the complete set of firms in Amadeus (approximately 8 million corporate names). For the EPO matching, our patent information source is the 2005 publication of the PATSTAT database, which is a standard source for European patent data and is published by the EPO. This database contains all European patent applications and granted patents from the beginning of the EPO system in 1978 to 2004. For the USPTO matching, we use an updated version of the National Bureau of Economic Research (NBER) patent file for the period 1975-2004. ${ }^{3}$ Appendix A.2. provides details about the patent matching procedure.

(iii) Accounting. Accounting information is taken primarily from current and historical versions of Amadeus. ${ }^{4}$ The source of the accounting information is usually the Company Register House in each of the countries included in our sample. The key advantage of these data is their large coverage of firms and unique accounting information on private firms. In addition to basic accounting information, we use Osiris (a database by BvDEP that focuses on public firms) to collect information on R\&D expenditures for the group public affiliates.

A total of 14,282 firms in Amadeus that report total assets also have at least one patent from the EPO or USPTO between 1975 and 2004. To avoid double counting, we drop all firms that do not report unconsolidated accounts, which leaves us with 12,669 firms. A total of 11,645 firms have at least one patent from the EPO. These firms hold, on average, 5.3 patents over the period 1978-2004. A total of 3,923 firms have at least one patent from the USPTO, with an average of approximately seven patents per firm over the period 1975-2004. The vast majority of our sample

\footnotetext{
${ }^{2}$ We use patents data to measure innovative activity because we do not have direct information on R\&D expenditures for private firms. For a discussion on the use of patents as a measure of inventive activity, see Griliches (1990).

${ }^{3}$ The NBER patent database is described by Hall et al. (2001) and Jaffe and Trajtenberg (2002).

${ }^{4}$ Firms that do not report accounting information for four consecutive years are dropped from the Amadeus database. To capture these dropped firms we use historical data from old Amadeus publications. We find that approximately $5 \%$ of firms are dropped from the database each year.
} 
Table 1 Summary Statistics

\begin{tabular}{|c|c|c|c|c|c|c|c|}
\hline \multirow[b]{2}{*}{ Variable } & \multirow[b]{2}{*}{ Firms/Groups } & \multirow[b]{2}{*}{ Obs. } & \multirow[b]{2}{*}{ Mean } & \multirow[b]{2}{*}{ Std. dev. } & \multicolumn{3}{|c|}{ Distribution } \\
\hline & & & & & 10th & 50th & 90th \\
\hline \multicolumn{8}{|c|}{ Panel A: Firms } \\
\hline No. of EPO Patents & 11,645 & 68,707 & 0.28 & 1.57 & 0 & 0 & 1 \\
\hline No. of USPTO Patents & 3,931 & 23,908 & 0.48 & 2.77 & 0 & 0 & 1 \\
\hline Total Assets $(, 000)$ & 12,672 & 74,706 & 41,840 & 110,140 & 202 & 5,604 & 102,646 \\
\hline Sales $(, 000)$ & 9,985 & 57,584 & 57,584 & 173,293 & 328 & 10,038 & 131,113 \\
\hline Return on Assets & 9,599 & 51,997 & 0.012 & 0.226 & -0.115 & 0.025 & 0.162 \\
\hline Firm Age & 11,617 & 69,190 & 24 & 22 & 5 & 17 & 54 \\
\hline Cash Flow $(, 000)$ & 12,223 & 67,978 & 3,074 & 22,469 & 4 & 255 & 4,935 \\
\hline \multicolumn{8}{|c|}{ Panel B: Business groups } \\
\hline No. of EPO Patents & 2,818 & 25,675 & 2.50 & 21.19 & 0 & 0 & 3 \\
\hline No. of USPTO Patents & 1,784 & 16,410 & 7.53 & 42.44 & 0 & 0 & 10 \\
\hline No. of Group Affiliates & 3,033 & 3,033 & 25 & 67 & 2 & 6 & 58 \\
\hline Sales (millions) & 3,033 & 27,769 & 1,680 & 10,817 & 5 & 72 & 2,063 \\
\hline Total Assets (millions) & 3,033 & 27,769 & 2,367 & 15,571 & 4 & 60 & 2,197 \\
\hline Cash Flow (millions) & 3,033 & 27,769 & 129 & 1,033 & 0.4 & 3 & 122 \\
\hline
\end{tabular}

Notes. This table provides summary statistics for innovative firms (panel A, firm-year) and business groups (panel B, group-year) for our estimation period 1995-2004. Financial values are in U.S. dollars. Patent data are taken from the EPO and USPTO. Return on Assets is profits over total assets. Firm Age is the number of years from date of incorporation. Cash Flow is net income plus depreciation. Business-group variables are based on the financials and patents of all group members, including noninnovating firms and American subsidiaries.

of innovating firms is private (only $1 \%$ of the firms in our sample are public), and approximately $45 \%$ of these firms are business-group affiliates.

Panel A of Table 1 provides descriptive statistics at the firm level. Our sample covers firms from a wide size distribution: the 10th percentile of annual sales is $\$ 0.3$ million, the median is approximately $\$ 10$ million, and the 90th percentile is $\$ 131$ million. Panel B of Table 1 provides group-level statistics. A total of 5,683 firms are affiliated with 3,033 different groups.
The distribution of the number of firms in each group is skewed with a median of six firms and an average of 25 firms (the 90th percentile is 58 firms). Sixty-five percent of the innovative affiliates belong to groups that include affiliates from more than one country, whereas $16 \%$ of the affiliates belong to groups that operate in only one three-digit SIC industry.

Table 2 reports summary statistics separately for affiliates and standalones. On average, an affiliated firm has approximately twice as many patents per

Table 2 Firm Characteristics: Affiliates vs. Standalones

\begin{tabular}{|c|c|c|c|c|c|c|c|c|c|}
\hline \multirow[b]{2}{*}{ Variable } & \multirow[b]{2}{*}{ Affiliates-Standalones } & \multicolumn{4}{|c|}{ Business-group affiliates } & \multicolumn{4}{|c|}{ Standalones } \\
\hline & & Obs. & Mean & Median & Std. dev. & Obs. & Mean & Median & Std. dev. \\
\hline \multicolumn{10}{|c|}{ Panel A: Innovating firms } \\
\hline No. of EPO Patents & $0.197^{* * *}$ & 33,464 & 0.375 & 0 & 1.954 & 35,213 & 0.178 & 0 & 1.045 \\
\hline No. of USPTO Patents & $0.335^{* * *}$ & 13,904 & 0.616 & 0 & 3.156 & 9,986 & 0.281 & 0 & 2.114 \\
\hline Total Assets $(, 000)$ & $43,780^{* * *}$ & 36,416 & 64,292 & 15,380 & 135,348 & 38,256 & 20,513 & 2,867 & 374 \\
\hline Sales $(, 000)$ & $69,696^{* * *}$ & 30,666 & 90,545 & 23,185 & 222,769 & 26,897 & 20,849 & 4,004 & 74,587 \\
\hline Age & $7.3^{* * *}$ & 34,139 & 28 & 21 & 24 & 35,034 & 21 & 15 & 19 \\
\hline Cash Flow & $2,491^{* * *}$ & 28,282 & 4,016 & 451 & 16,151 & 29,155 & 1,525 & 137 & 9,072 \\
\hline Sales/Employee $(, 000)$ & $128^{* * *}$ & 22,351 & 387 & 181 & 4,014 & 16,639 & 259 & 152 & 1,133 \\
\hline \multicolumn{10}{|c|}{ Panel B: Innovating and noninnovating firms } \\
\hline No. of EPO Patents & $0.223^{* * *}$ & 117,262 & 0.248 & 0 & 4.469 & 399,891 & 0.025 & 0 & 1.475 \\
\hline No. of USPTO Patents & $0.123^{* * *}$ & 117,262 & 0.138 & 0 & 8.274 & 399,891 & 0.015 & 0 & 2.359 \\
\hline Total Assets $(, 000)$ & $22,134^{* * *}$ & 117,262 & 29,272 & 6,351 & 81,201 & 399,891 & 7,138 & 2,397 & 27,555 \\
\hline Sales $(, 000)$ & $33,195^{* * *}$ & 117,262 & 42,347 & 9,508 & 151,705 & 399,891 & 9,152 & 3,083 & 45,727 \\
\hline Age & $4.3^{* * *}$ & 116,654 & 20 & 15 & 19 & 395,050 & 16 & 13 & 14 \\
\hline Cash Flow & $1,698^{* * *}$ & 108,473 & 2,154 & 373 & 16,418 & 382,651 & 457 & 138 & 4,305 \\
\hline Sales/Employee $(, 000)$ & $423^{* * *}$ & 97,200 & 1,049 & 296 & 16,935 & 263,819 & 626 & 239 & 4,088 \\
\hline
\end{tabular}

Notes. This table provides summary statistics for group affiliates and standalones in our sample. Panel A describes innovating firms. Data are annual for the period 1995-2004. Panel B includes also noninnovating firms and is cross-sectional for the most recent year for which firms report financial information. Patent data include all granted patents in the period 1978-2004 for the EPO and 1975-2004 for the USPTO.

***Implies that the difference in means between affiliates and standalones is significant at the $1 \%$ level. 
year than a standalone ( 0.375 versus 0.178$)$ and is substantially larger (the average affiliate has approximately $\$ 64$ million in total assets as compared with $\$ 20.5$ million for the average standalone).

\section{Econometric Framework}

\subsection{Baseline Specification}

We use the negative binomial model to analyze our patent count data. Models for count data assume a first moment of the form ${ }^{5}$ :

$$
E\left(P_{i t} \mid X_{i t}\right)=\exp \left(x_{i t}^{\prime} \beta\right),
$$

where $E(\cdot \mid \cdot)$ is the conditional expectations operator and $P_{i t}$ is a count of the number of patents. We introduce firm-fixed effects into the count data model using the "mean scaling" method of Blundell et al. (1999). This method relaxes the strict exogeneity assumption underlying Hausman et al. (1984). Essentially, we exploit the fact that we have a long pre-sample history (of up to 20 years per firm) on patenting activity to construct a pre-sample average of the annual number of patents. This is then used as an initial condition to proxy for unobserved heterogeneity. The conditional expectation we estimate is ${ }^{6}$

$$
\begin{array}{r}
E\left(P_{i t} \mid X_{i t}\right)=\exp \left\{\beta_{1} \text { Group }_{i}+\beta_{2} \ln \text { Assets }_{i t-1}\right. \\
\left.+Z_{i t}^{\prime} \beta_{3}+\varphi_{j}+\tau_{t}+\eta_{i}\right\},
\end{array}
$$

where Group is a dummy with value 1 if the firm belongs to a business group and value 0 if the firm is a standalone. Assets it-1 $_{\text {is }}$ ised to control for firm size (we use lagged value to mitigate transitory shocks that can affect both the incentive to innovate and size), $Z_{i t}$ is a vector of other controls, $\varphi_{j}$ and $\tau_{t}$ are complete sets of three-digit industry SIC and year dummies, and $\eta_{i}$ is the firm fixed effect.

Given the panel structure of our data, we correct the standard errors for serial correlation. This is especially important because the group dummy is constant over time within firms. The reported standard errors are always robust to arbitrary heteroskedasticity and allow for serial correlation within firms.

\subsection{Dealing with Potential Biases}

3.2.1. Endogeneity Bias: "Winner Picking." In our baseline specification, we estimate the relation

\footnotetext{
${ }^{5}$ See Blundell et al. (1999) and Hausman et al. (1984) for discussions of count data models of innovation.

${ }^{6}$ The variance of the negative binomial under our specification is

$$
V\left(P_{i t}\right)=\exp \left(x_{i t}^{\prime} \beta\right)+\alpha \exp \left(2 x_{i t}^{\prime} \beta\right),
$$
}

where the parameter, $\alpha$, is a measure of "overdispersion," relaxing the Poisson restriction that the mean equals the variance $(\alpha=0)$. between business-group affiliation and innovation $\left(\beta_{1}\right)$. If selection into business groups is endogenous, our coefficient estimates are likely to be biased. More specifically, if groups engage in winner picking, i.e., group affiliation is positively correlated with an unobserved "quality" variable, then $\beta_{1}$ would be upward biased. We mitigate this concern in several ways. First, we keep in our sample only firms that maintain their affiliation status between 1997 and 2004. We use BvDEP's mergers and acquisition database, Zephyr, to examine changes in group affiliation. Approximately $5 \%$ of firms in our complete sample experience a change in their ownership structure; these firms are excluded from our estimation sample. ${ }^{7}$ Second, we compute the average number of patents that each firm had prior to our sample period (from the grant year of the firm's first patent until the first year in which the firm appears in the estimation sample). This variable is used as a proxy for the unobserved heterogeneity at the beginning of our sample (Blundell et al. 1999). Third, we mitigate the potential group selection bias by testing specifications with only affiliated firms. In these specifications, we exploit the variation in group structure to learn about the potential channels that may explain why groups facilitate innovation.

3.2.2. Sample Selection: Innovating Firms. Groups may assign all of their patents to a single firm. This means that an affiliated firm can appear to have numerous patents even though it is hardly engaged in the R\&D process, leading to an upward bias in $\beta_{1}$. To deal with the potential patent assignment bias, we estimate the affiliation-innovation relationship for virtually all firms in the economy (approximately 500,000 firms that report accounting information and have at least $\$ 1$ million in assets). Including noninnovating firms is likely to mitigate the estimation bias because the effect of the patent-hub affiliates on the coefficient would be offset by the other group members whose patents were reassigned. In addition, we estimate group-level specifications and examine the relation between group characteristics and the aggregated number of group patents. In these specifications the specific assignment of patents within the group is irrelevant for the estimation analysis.

\footnotetext{
${ }^{7}$ Approximately 200 innovative firms have entered a group between 1997 and 2004. We use this sample to estimate a probit model of group selection against a set of firm characteristics, including EPO and USPTO patent stocks. We find limited evidence that new group entrants are more innovative than nonentrant firms. While we find no sorting on patents when comparing entrants to incumbent affiliates, entrants appear to be more innovative than nonentrant standalones.
} 
3.2.3. Unit of Observation. In the econometric analysis, we use observations at the firm level. Namely, we compare a group-affiliated firm to a standalone firm (and not an entire group to a standalone firm) because they are legally, empirically, and economically comparable. Because this issue may relate to the more general discussion about the boundaries of the firm, we specify the reasons leading us to this choice. First, similar to standalone firms, affiliated firms are legally independent entities. This means that each firm has its own CEO, board of directors, financial statements, etc. Second, groups are highly diversified across industries and are larger by an order of magnitude than standalones (e.g., the average business group has aggregate annual sales of more than $\$ 1.7$ billion compared to $\$ 57$ million of an average standalone). These differences make groups and standalones econometrically and economically incomparable. We use various observed firm characteristics to control for the remaining differences between affiliates and standalones.

\subsection{Group Internal Capital Markets}

3.3.1. Industry External Dependence. If groups facilitate innovation because they provide their affiliates with cheaper external funds, we expect the group-innovation relation to be stronger in industries where firms rely more on external finance. We follow Rajan and Zingales (1998) and rank industries according to their dependence on external finance. In computing measures of external dependence, we use U.S. Compustat firms. As discussed by Rajan and Zingales (1998), using U.S. firms has important advantages: (i) Because the U.S. market is one of the most advanced capital markets in the world, American firms face the least friction in accessing finance. This means that the amount of external finance used by these companies is likely to be a pure measure of their demand for external finance. (ii) Disclosure requirements imply that data on external financing are comprehensive. (iii) While using U.S. industry data is rather exogenous to European firms, it is likely that an industry's dependence on external funds in the United States is a good measure of external dependence in European countries. Moreover, business groups are very rare in the United States, where tax and regulatory hurdles impose high costs on maintaining a business group (La Porta et al. 1999, Morck 2005). This allows us to obtain a rather "clean" measure of firms' demand for external finance in a business-group-free environment. The main two assumptions needed are that technological differences explain why some industries rely on external funds more than others and that these differences persist across countries. We compute two measures of external dependence: External Finance Dependence and
External Equity Dependence. External Finance Dependence is the ratio between capital expenditures minus cash flow from operations and capital expenditures. External Equity Dependence is the ratio between the net amount of equity issued and capital expenditures.

Our empirical specification now becomes

$$
\begin{aligned}
E\left(P_{i t} \mid X_{i t}\right) & \\
=\exp & \left\{\beta_{1} \text { Group }_{i}+\beta_{2} \text { Group }_{i}\right. \\
& \times \text { Industry External Dependence }_{j} \\
& +\beta_{3} \ln \text { Assets }_{i t-1}+Z_{i t}^{\prime} \beta_{4}+\varphi_{j} \\
& \left.+\eta_{i}+\tau_{t}\right\} .
\end{aligned}
$$

Our main interest is in the coefficient $\beta_{2}$, where the internal capital markets hypothesis implies $\beta_{2}>0$.

3.3.2. Group Diversification. We explore the relation between group diversification and innovation by estimating group-level specifications. Following Palepu (1985), group diversification is estimated using Entropy measures over the period 1995-2004. The Entropy measures include Total Diversification (TD), Related Diversification (RD), and Unrelated Diversification (UD) and are constructed as follows. Suppose a business group operates in $N$ segments that belong to $M$ industries. We use three-digit and two-digit SIC codes to define segments and industries, respectively. We denote by $P_{i}^{j}$ the share of the $i$ th segment sales of total group sales in industry $j$. Related Diversification measures the extent to which the group operates in several business segments within an industry and is defined as

$$
R D_{j}=\sum_{i \in j} P_{i}^{j} \ln \left(\frac{1}{P_{i}^{j}}\right) .
$$

If a firm operates in several industries, its aggregated related diversification is the weighted sum of $R D_{j}$, where the weight, $P^{j}$, is the share of industry $j$ sales of the group's total sales:

$$
R D=\sum_{j \in M} R D_{j} P_{j} .
$$

Unrelated Diversification measures the extent to which business-group sales spread across different (two-digit) industries and is defined as

$$
U D=\sum_{j \in M} P_{j} \ln \left(\frac{1}{P_{j}}\right) .
$$

Last, Total Diversification is a weighted average of the firm's diversification within and between sectors and is computed as the sum of $R D$ and $U D$, or as

$$
\mathrm{TD}=\sum_{i \in N} P_{i} \ln \left(\frac{1}{P_{i}}\right) .
$$


In the group-level analysis we include all business groups regardless of whether they innovate. We exclude economically insignificant groups by dropping groups that generate less than $\$ 10$ million in annual sales. We control for a wide set of group characteristics, such as total assets, pre-sample number of patents, distribution of sales across countries, and family ownership. In constructing group measures, we include all available information (accounting and patents) for all group members even if they do not appear in our firm-level specifications.

\subsection{Knowledge Spillovers}

Since the seminal papers by Griliches (1979) and Scherer (1982), an expanding literature has documented the positive effect of knowledge spillovers on innovation. If the frequency and magnitude of knowledge spillovers are higher within groups, this can lead to a positive effect of group affiliation on innovation. To test this hypothesis, we take two steps. First, we examine the degree of similarity in the research conducted by firms in the same group. According to the knowledge spillovers hypothesis, we expect firms in the same group to have similar R\&D focus. We follow Jaffe (1986) and compute a measure of technological similarity between firm pairs that is based on the degree of overlap in the technology fields where patenting takes place. The research similarity index for each pair of firms ( $i$ and $j$ ) is computed in the following way:

$$
\operatorname{TEC}_{i j}=\frac{\left(T_{i} T_{j}^{\top}\right)}{\left(T_{i} T_{i}^{\top}\right)^{1 / 2}\left(T_{j} T_{j}^{\top}\right)^{1 / 2}},
$$

where $T$ is a vector representing the firm's share of patents in the four-digit technology sectors. The technology space information is provided by the allocation of all patents by the EPO into 623 different technology classes (International Patent Classification). We use the average share of patents per firm in each technology class over the period 1978-2004 to generate the following vector for each firm: $T_{i}=$ $\left(T_{i, 1}, T_{i, 2}, \ldots, T_{i, 426}\right)$, where $T_{i, m}$ is the share of patents of firm $i$ in technology class $m$. TEC $i$ can receive values ranging from zero to one (where values closer to zero imply that the research programs of the two firms are more orthogonal for one another).

Second, we explore the pattern of citations made by group affiliates. If groups facilitate innovation by intensifying knowledge spillovers between group members, we expect a substantial fraction of the citations made by group affiliates to be directed to patents of other affiliates of the same group.

\section{Results}

\subsection{Group Affiliation and Innovation}

Group affiliation is endogenous and is likely to be affected by firm and industry characteristics. Table 3 reports probit estimation results for the determinants of group affiliation using the complete set of Amadeus firms, regardless of whether they innovate. The sample is cross-sectional and includes all firms that report accounting information (total assets, cash flow, profits, and date of incorporation) and have at least $\$ 1$ in assets. We exclude very large firms (firms that hold more than $\$ 1$ billion in assets) because these firms are likely to face different organizational form considerations. Several interesting findings come from the analysis. First, we find that while only $22 \%$ of the firms in our sample belong to groups, approximately $75 \%$ of the patents are assigned to group affiliates (where approximately $55 \%$ of total assets are concentrated in groups). Second, the probit estimation results indicate that group affiliates are typically larger, less profitable, and older and hold less cash than standalones. ${ }^{8}$ Third, group affiliation is more likely in R\&D-intensive industries, ${ }^{9}$ which is consistent with the view that business groups foster innovation. Conditional on R\&D intensity, groups are also more prevalent in industries with higher external dependence, as implied by the internal capital market hypothesis.

We proceed with parametric and nonparametric estimations of the group-innovation relationship. Table 4 reports the results for the parametric regressions, which imply a positive and significant relation between group affiliation and innovation. Columns 1-4 examine the group-innovation relation for the number of EPO patents. Column 1 includes a business affiliation dummy, which receives the value of 1 for affiliates and zero for standalones. The coefficient estimate on this dummy is positive and highly significant (a coefficient of 0.394 and a standard error of 0.053 ). In columns $2-4$ we focus on more flexible definitions of group affiliation. Column 2 includes the number of firms in the group (for standalones this variable receives the value of one). There is a strong positive relation between the number of group affiliates and patents. In columns 3 and 4 we divide groups into three categories: small groups (two or three affiliated firms), medium groups (between four and 50 affiliated firms), and large groups (more than 50 affiliated firms). We include a dummy variable

\footnotetext{
${ }^{8}$ Finding that affiliates are less cash abundant is consistent with the cash-holding view; accordingly, diversified organizations require less cash to finance new investment opportunities than specialized ones (Duchin 2010).

${ }^{9}$ We compute R\&D intensity as the industry average ratio of $R \& D$ expenditures and sales using Compustat firms.
} 
Dependent variable: Business-Group Dummy

\begin{tabular}{|c|c|c|c|c|c|c|}
\hline & (1) & $(2)$ & (3) & $(4)$ & $(5)$ & (6) \\
\hline \multicolumn{7}{|l|}{ Firm characteristics: } \\
\hline In(Total Assets) & $\begin{array}{l}0.432^{* * *} \\
(0.003)\end{array}$ & $\begin{array}{l}0.428^{* * *} \\
(0.003)\end{array}$ & $\begin{array}{l}0.428^{* * *} \\
(0.002)\end{array}$ & $\begin{array}{l}0.429 * * * \\
(0.002)\end{array}$ & $\begin{array}{l}0.431^{* * *} \\
(0.003)\end{array}$ & $\begin{array}{l}0.429 * * * \\
(0.002)\end{array}$ \\
\hline In(Cash Flow) & $\begin{array}{c}-0.042^{* * *} \\
(0.001)\end{array}$ & $\begin{array}{c}-0.040^{* * *} \\
(0.001)\end{array}$ & $\begin{array}{c}-0.034^{* * *} \\
(0.001)\end{array}$ & $\begin{array}{c}-0.034^{* * *} \\
(0.001)\end{array}$ & $\begin{array}{c}-0.033^{* * *} \\
(0.001)\end{array}$ & $\begin{array}{c}-0.034^{* * *} \\
(0.001)\end{array}$ \\
\hline Return on Assets & & $\begin{array}{c}-0.260^{* * *} \\
(0.019)\end{array}$ & $\begin{array}{c}-0.269^{* * * *} \\
(0.019)\end{array}$ & $\begin{array}{c}-0.268^{* * *} \\
(0.019)\end{array}$ & $\begin{array}{c}-0.282^{* * *} \\
(0.020)\end{array}$ & $\begin{array}{c}-0.268^{* * *} \\
(0.019)\end{array}$ \\
\hline $\ln ($ Firm Age $)$ & & $\begin{array}{l}0.015^{* * *} \\
(0.003)\end{array}$ & $\begin{array}{l}0.014^{* * *} \\
(0.003)\end{array}$ & $\begin{array}{l}0.016^{* * *} \\
(0.003)\end{array}$ & $\begin{array}{l}0.019 * * * \\
(0.003)\end{array}$ & $\begin{array}{l}0.015^{* * *} \\
(0.003)\end{array}$ \\
\hline \multicolumn{7}{|l|}{ Industry characteristics: } \\
\hline$R \& D$ Intensity (R\&D/Sales) & & & $\begin{array}{l}0.012^{* * *} \\
(0.001)\end{array}$ & $\begin{array}{l}0.010^{* * *} \\
(0.001)\end{array}$ & $\begin{array}{l}0.010^{* * *} \\
(0.001)\end{array}$ & $\begin{array}{l}0.011^{* * *} \\
(0.001)\end{array}$ \\
\hline External Finance Dependence & & & & $\begin{array}{l}0.019^{* * *} \\
(0.003)\end{array}$ & & $\begin{array}{l}0.017^{* * *} \\
(0.003)\end{array}$ \\
\hline External Equity Dependence & & & & & $\begin{array}{l}0.022^{* * *} \\
(0.002)\end{array}$ & \\
\hline Lerner Index of Competition & & & & & & $\begin{array}{c}0.003 \\
(0.038)\end{array}$ \\
\hline Three-digit SIC dummies & Yes & Yes & No & No & No & No \\
\hline$R^{2}$ & 0.303 & 0.304 & 0.292 & 0.298 & 0.298 & 0.292 \\
\hline Observations & 477,999 & 477,999 & 477,999 & 477,999 & 477,999 & 477,999 \\
\hline Number of affiliate firms (\%) & 22 & 22 & 22 & 22 & 22 & 22 \\
\hline Affiliates' number of EPO patents (\%) & 74 & 74 & 74 & 74 & 74 & 74 \\
\hline Affiliates' number of USPTO patents (\%) & 73 & 73 & 73 & 73 & 73 & 73 \\
\hline Affiliates' total assets (\%) & 54 & 54 & 54 & 54 & 54 & 54 \\
\hline
\end{tabular}

Notes. This table reports the results of probit regressions that examine the relation between group affiliation and firm and industry characteristics. The sample is cross-sectional and includes all firms in Amadeus (innovating and noninnovating) that report accounting information (total assets, cash flow, profits, and date of incorporation) and have at least $\$ 1$ in assets. Cash Flow is net income plus depreciation. Return on Assets is profits over total assets. Age is the number of years since the date of incorporation. R\&D Intensity, External Finance Dependence and External Equity Dependence are computed as the average three-digit SIC level for the period 1995-2004 based on Compustat firms. R\&D intensity is the ratio between R\&D expenditures and sales. External Finance Dependence is the ratio between capital expenditures minus cash flow from operations and capital expenditures. External Equity Dependence is the net amount of equity issued over capital expenditures. Lerner Index of Competition is based on British firms and is computed as the three-digit industry average of 1 minus profits over sales for the period 1995-2004. All regressions include a complete set of country dummies. Standard errors (in parentheses) are robust to arbitrary heteroskedasticity.

*Significant at $10 \%$; ${ }^{* *}$ significant at $5 \%$; ${ }^{* * *}$ significant at $1 \%$.

for each category, using standalones as the baseline category. We find that the group-innovation relation intensifies with the number of group affiliates in each category (the coefficients on small, medium, and large are 0.204, 0.409, and 0.614, respectively). Column 4 reports the estimation results using a sample of only affiliated firms. Comparing affiliates of large groups to affiliates of small ones, we continue to find a positive relation between group size and innovation. In columns 5-8 we replicate the analysis for the number of USPTO and find that the general pattern continues to hold. Yet not all patents are created equal. In fact, patents may vary greatly in terms of their quality. In columns 9 and 10 we employ a common method to control for patent quality by counting the number of citations each patent receives (excluding selfcitations). Our findings indicate that business-group affiliation enhances not only the number of patents an affiliated firm generates but also the average number of citations its patents receive.

Table 5 reports propensity-score matching estimation results that aim to mitigate the potential bias that may arise from including only innovating firms and to expand the set of firm controls that are likely to affect both group affiliation and innovation. Specification 1 in Table 3 is the "first-stage" regression for the propensity matching estimation. To limit the computing power needed to run this specification, we select a random sample of $20 \%$ of the 477,999 firms from Table 3 while not conditioning on whether they patent. Similar to the parametric results reported in Table 4, the nonparametric results also point toward a strong positive relation between group affiliation and innovation. Also, we find that group affiliation is positively related not only to the level of innovation but also to the decision of whether to innovate (column 6). 
Table 4 Business-Group Affiliation and Innovation

\begin{tabular}{|c|c|c|c|c|c|c|c|c|c|c|}
\hline \multirow{3}{*}{$\begin{array}{l}\text { Dependent variable: } \\
\text { Firms: }\end{array}$} & (1) & $(2)$ & (3) & (4) & (5) & (6) & (7) & (8) & (9) & (10) \\
\hline & \multicolumn{4}{|c|}{ Number of EPO Patents } & \multicolumn{4}{|c|}{ Number of USPTO Patents } & \multicolumn{2}{|c|}{$\begin{array}{l}\text { Citations/Patents } \\
\quad(E P O), O L S\end{array}$} \\
\hline & All & All & All & Only affiliates & All & All & All & Only affiliates & All & All \\
\hline Business-Group Dummy & $\begin{array}{l}0.394^{* * *} \\
(0.053)\end{array}$ & & & & $\begin{array}{l}0.158^{* * *} \\
(0.071)\end{array}$ & & & & $\begin{array}{l}0.026^{* * *} \\
(0.008)\end{array}$ & \\
\hline In(No. of Firms) & & $\begin{array}{l}0.111^{* * *} \\
(0.017)\end{array}$ & & & & $\begin{array}{l}0.067^{* * *} \\
(0.021)\end{array}$ & & & & \\
\hline $\begin{array}{l}\text { Small-Group Dummy } \\
\quad(2 \leq \text { No. of Firms } \leq 3)\end{array}$ & & & $\begin{array}{l}0.204^{* * *} \\
(0.061)\end{array}$ & & & & $\begin{array}{l}-0.047 \\
(0.084)\end{array}$ & & & $\begin{array}{l}0.019 * * \\
(0.010)\end{array}$ \\
\hline $\begin{array}{l}\text { Medium-Group Dummy } \\
\quad(4 \leq \text { No. of Firms } \leq 50)\end{array}$ & & & $\begin{array}{l}0.409^{* * *} \\
(0.060)\end{array}$ & $\begin{array}{l}0.175^{* * *} \\
(0.066)\end{array}$ & & & $\begin{array}{l}0.231^{* * *} \\
(0.085)\end{array}$ & $\begin{array}{l}0.221^{* *} \\
(0.090)\end{array}$ & & $\begin{array}{l}0.027^{* * *} \\
(0.009)\end{array}$ \\
\hline $\begin{array}{l}\text { Large-Group Dummy } \\
\quad(\text { No. of Firms }>50)\end{array}$ & & & $\begin{array}{l}0.614^{* * *} \\
(0.089)\end{array}$ & $\begin{array}{l}0.393^{* * *} \\
(0.090)\end{array}$ & & & $\begin{array}{l}0.346^{* * *} \\
(0.109)\end{array}$ & $\begin{array}{l}0.333^{* * *} \\
(0.113)\end{array}$ & & $\begin{array}{l}0.039 * * * \\
(0.013)\end{array}$ \\
\hline$[\ln (\text { Total Assets })]_{t-1}$ & $\begin{array}{l}0.239^{* * *} \\
(0.015)\end{array}$ & $\begin{array}{l}0.228^{* * *} \\
(0.016)\end{array}$ & $\begin{array}{l}0.224^{* * *} \\
(0.016)\end{array}$ & $\begin{array}{l}0.240^{* * *} \\
(0.022)\end{array}$ & $\begin{array}{l}0.294^{* * *} \\
(0.019)\end{array}$ & $\begin{array}{l}0.292^{* * *} \\
(0.020)\end{array}$ & $\begin{array}{l}0.276^{* * *} \\
(0.019)\end{array}$ & $\begin{array}{l}0.305^{* * *} \\
(0.025)\end{array}$ & $\begin{array}{l}0.013^{* * *} \\
(0.002)\end{array}$ & $\begin{array}{l}0.012^{* * *} \\
(0.002)\end{array}$ \\
\hline Pre-sample mean & $\begin{array}{l}0.685^{* * *} \\
(0.108)\end{array}$ & $\begin{array}{l}0.663^{* * *} \\
(0.108)\end{array}$ & $\begin{array}{l}0.669^{* * *} \\
(0.108)\end{array}$ & $\begin{array}{l}0.639^{* * *} \\
(0.137)\end{array}$ & $\begin{array}{r}0.415^{*} \\
(0.235)\end{array}$ & $\begin{array}{r}0.400^{*} \\
(0.231)\end{array}$ & $\begin{array}{c}0.404^{*} \\
(0.232)\end{array}$ & $\begin{array}{l}0.283 \\
(0.229)\end{array}$ & $\begin{array}{c}0.002 \\
(0.004)\end{array}$ & $\begin{array}{l}0.002 \\
(0.004)\end{array}$ \\
\hline $\begin{array}{l}\text { Log pseudo } \\
\text { likelihood } / R^{2}\end{array}$ & $-32,511.8$ & $-32,491.5$ & $-32,473.2$ & $-19,024.6$ & $-16,799.7$ & $-16,784.5$ & $-16,781.6$ & $-11,560.5$ & 0.020 & 0.020 \\
\hline Observations & 68,144 & 68,144 & 68,144 & 33,201 & 23,748 & 23,748 & 23,748 & 23,748 & 68,144 & 68,144 \\
\hline
\end{tabular}

Notes. This table reports the results of negative binomial regressions that examine the relation between business-group affiliation and innovation (firm-year) for a sample of innovative firms (firms with at least one EPO or USPTO patent). Data are for the period 1995-2004. The number of firms in a group includes all firms in the ownership database. Following the "pre-sample mean scaling approach" of Blundell et al. (1999), our pre-sample fixed effect is the yearly average number of patents a firm had until the first year it appeared in our sample. All regressions include complete sets of country, industry, and year dummies. Standard errors (in parentheses) are robust to arbitrary heteroskedasticity and allow for serial correlation through clustering by firm.

*Significant at $10 \% ;{ }^{* *}$ significant at $5 \% ;{ }^{* *}$ significant at $1 \%$.

"Soft budget" constraints may lead firms affiliated with large groups that have abundant resources to invest in low-quality research. This means that the extra resources provided by groups lead to more innovation but not to an increase in innovation quality and importance. To test this argument, we estimate a production function and profitability specifications. Presumably, higher-quality innovation would have a stronger effect on the productivity and profitability of the innovating firm. We examine the "soft budget" hypothesis by testing whether the innovation-performance relation is stronger for standalones than for affiliates. Table 6 reports the estimation results. The innovation-performance relation is always stronger for affiliates than for standalones, implying not only that group affiliates innovate more intensively than standalones but also that their innovation is more important for their subsequent performance. We also examine innovation quality using patent citations. On average, an EPO patent in our

Table $5 \quad$ Nonparametric Propensity-Score Estimation

\begin{tabular}{|c|c|c|c|c|c|c|}
\hline \multirow[b]{2}{*}{ Outcome variable: } & (1) & $(2)$ & (3) & (4) & $(5)$ & (6) \\
\hline & \multicolumn{2}{|c|}{ Diff. EPO Patents } & \multicolumn{2}{|c|}{ Diff. USPTO Patents } & \multicolumn{2}{|c|}{ Diff. Patenting Dummy } \\
\hline & Unmatched & Matched & Unmatched & Matched & Matched & Unmatched \\
\hline Business-Group Dummy & $\begin{array}{l}0.252^{* * *} \\
(0.019)\end{array}$ & $\begin{array}{l}0.088^{* * *} \\
(0.018)\end{array}$ & $\begin{array}{l}0.114^{* * *} \\
(0.008)\end{array}$ & $\begin{array}{l}0.044^{* * *} \\
(0.010)\end{array}$ & $\begin{array}{l}0.028^{* * *} \\
(0.001)\end{array}$ & $\begin{array}{l}0.006^{* * *} \\
(0.001)\end{array}$ \\
\hline Standalones & 74,346 & 74,346 & 74,346 & 74,346 & 74,346 & 74,346 \\
\hline Affiliates & 21,254 & 21,254 & 21,254 & 21,254 & 21,254 & 21,254 \\
\hline Sample average & 0.086 & 0.086 & 0.046 & 0.046 & 0.014 & 0.014 \\
\hline
\end{tabular}

Notes. This table reports the results of a nonparametric propensity-score matching estimation (using the nearestneighbor method) of the relation between business-group affiliation and innovation for a sample of innovating and noninnovating firms. The first-stage regression for Business-Group Dummy is specification 1 in Table 3 . To limit the computing power needed to run the nonparametric specifications, we select a random sample of $20 \%$ of the firms in Table 3 (not conditioning on patenting).

${ }^{*}$ Significant at $10 \% ;{ }^{* *}$ significant at $5 \% ;{ }^{* * *}$ significant at $1 \%$. 
Table 6

Innovation, Group Affiliation, and Firm Performance

\begin{tabular}{|c|c|c|c|c|c|c|c|c|}
\hline \multirow{3}{*}{$\begin{array}{l}\text { Dependent variable: } \\
\text { Firms: }\end{array}$} & (1) & (2) & (3) & (4) & (5) & (6) & $(7)$ & (8) \\
\hline & \multicolumn{4}{|c|}{$\log ($ Sales $)$} & \multicolumn{4}{|c|}{ Profits/Sales } \\
\hline & All & Affiliates & Standalones & All & All & Affiliates & Standalones & All \\
\hline$[\ln (\text { Employees })]_{t-1}$ & $\begin{array}{l}0.778^{* * *} \\
(0.005)\end{array}$ & $\begin{array}{l}0.744^{* * *} \\
(0.006)\end{array}$ & $\begin{array}{l}0.756^{* * *} \\
(0.008)\end{array}$ & $\begin{array}{l}0.756^{* * *} \\
(0.005)\end{array}$ & $\begin{array}{l}0.003^{* * *} \\
(0.001)\end{array}$ & $\begin{array}{c}-0.001 \\
(0.001)\end{array}$ & $\begin{array}{l}0.006^{* * *} \\
(0.001)\end{array}$ & $\begin{array}{l}0.002^{* *} \\
(0.001)\end{array}$ \\
\hline$[\ln (\text { Capital })]_{t-1}$ & $\begin{array}{l}0.203^{* * *} \\
(0.004)\end{array}$ & $\begin{array}{l}0.193^{* * *} \\
(0.004)\end{array}$ & $\begin{array}{l}0.191^{* * *} \\
(0.006)\end{array}$ & $\begin{array}{l}0.196^{* * *} \\
(0.004)\end{array}$ & $\begin{array}{c}-0.001 \\
(0.001)\end{array}$ & $\begin{array}{l}0.002^{* * *} \\
(0.001)\end{array}$ & $\begin{array}{l}-0.005^{* * *} \\
(0.001)\end{array}$ & $\begin{array}{c}-0.001 \\
(0.001)\end{array}$ \\
\hline$[\ln (\text { Patents Stock })]_{t-1}$ & $\begin{array}{l}0.054^{* * *} \\
(0.007)\end{array}$ & $\begin{array}{l}0.064^{* * *} \\
(0.008)\end{array}$ & $\begin{array}{l}0.037^{* * *} \\
(0.015)\end{array}$ & $\begin{array}{l}0.035^{* * *} \\
(0.008)\end{array}$ & $\begin{array}{l}0.003^{* * *} \\
(0.001)\end{array}$ & $\begin{array}{l}0.004^{* * *} \\
(0.001)\end{array}$ & $\begin{array}{c}-0.001 \\
(0.002)\end{array}$ & $\begin{array}{l}0.001 \\
(0.001)\end{array}$ \\
\hline $\begin{array}{l}{[\ln (\text { Patents Stock })]_{t-1}} \\
\quad \times \text { Business-Group Dummy }\end{array}$ & & & & $\begin{array}{l}0.023^{* * *} \\
(0.007)\end{array}$ & & & & $\begin{array}{l}0.003^{* * *} \\
(0.001)\end{array}$ \\
\hline Business-Group Dummy & & & & $\begin{array}{l}0.293^{* * *} \\
(0.011)\end{array}$ & & & & $\begin{array}{l}0.007^{* * *} \\
(0.002)\end{array}$ \\
\hline$R^{2}$ & 0.831 & 0.807 & 0.810 & 0.834 & 0.025 & 0.046 & 0.029 & 0.025 \\
\hline Observations & 39,998 & 23,194 & 16,804 & 39,998 & 37,746 & 22,292 & 15,454 & 37,746 \\
\hline
\end{tabular}

Notes. This table reports OLS estimation results of the relation between patents stock and firm productivity and profitability (firm-year) for a sample of innovating firms (firms with at least one EPO or USPTO patent). Patents stock is computed using the perpetual inventory method with a depreciation rate of $15 \%$ and is taken from the EPO. All regressions include complete sets of three-digit industry, country, and year dummies. Standard errors (in parentheses) are robust to arbitrary heteroskedasticity and allow for serial correlation through clustering by firm.

*Significant at $10 \%$; ** significant at $5 \% ;{ }^{* * *}$ significant at $1 \%$.

sample receives 2.44 citations. For patents held by standalones, the average number of citations per patent is 1.06, and for affiliates it is 3.28. This difference in citations between affiliates and standalones is statistically significant at the $1 \%$ level (with a $t$ statistic of 7.68). This pattern is also confirmed in columns 9 and 10 of Table 4, where we show that patents by group affiliates tend to receive more citations than patents of comparable standalones.

\subsection{Group Internal Capital Markets}

Our test of the internal capital markets hypothesis is twofold. First, we explore whether affiliation is more important for innovation in industries that rely more on external funds. Second, we estimate group-level specifications and investigate the relation between group diversification and innovation.

We examine the interaction of the business-group dummy with two variables: External Finance Dependence and External Equity Dependence. Table 7 reports the estimation results. First we interact the group affiliation dummy with industry $R \& D$ intensity. If groups provide innovation-specific benefits, we expect affiliation to be more important for innovation in industries with higher R\&D intensity. As expected, the coefficient on the interaction between group affiliation and $R \& D$ intensity is positive and significant $(0.038$ with a standard error of 0.015). Columns $2-7$ report the estimation results for the interaction between group affiliation and industry external dependence. The results support the internal capital markets hypothesis. The coefficients on the interaction terms between group affiliation and the external dependence variables are positive and highly significant (0.087 with a standard error of 0.034 and 0.078 with a standard error of 0.033 for external finance dependence and external equity dependence, respectively). When adding the interaction terms of external dependence, the coefficient on R\&D intensity becomes insignificant ( 0.017 with a standard error of 0.016). The same pattern of results holds when controlling for additional firm characteristics that we have found to be correlated with group affiliation, including Cash Flow, Return on Assets, and Firm Age (columns 4 and 7).

Our second test of the group internal capital markets hypothesis examines the relation between group diversification and innovation. ${ }^{10}$ According to the internal capital markets hypothesis, we expect a positive relation between group-unrelated diversification and innovation. Table 8 reports the estimation results. Our evidence supports the internal capital markets hypothesis. We find a positive and significant coefficient on unrelated diversification, where the coefficient on related diversification is never significant (0.867 with a standard error of 0.070 , and 0.002 with a standard error of 0.047 for unrelated and related diversification, respectively).

R\&D data allow distinguishing between the level of innovation and innovation productivity. A research program is considered to be more productive as the number of patents it generates, conditional on R\&D investment, increases. We typically do not have information on R\&D at the subsidiary level because most affiliates are private firms that do not report their

\footnotetext{
${ }^{10}$ The average values of related, unrelated, and total diversification for all groups are $0.08,0.37$, and 0.44 , respectively (medians of 0 , 0.22 , and 0.29 ).
} 
Table 7

Industry External Dependence

Dependent variable: Number of EPO Patents

\begin{tabular}{|c|c|c|c|c|c|c|c|}
\hline \multirow[b]{2}{*}{ Industry measure: } & \multicolumn{4}{|c|}{ External finance dependence } & \multicolumn{3}{|c|}{ External equity dependence } \\
\hline & $(1)$ & $(2)$ & (3) & $(4)$ & (5) & (6) & $(7)$ \\
\hline Business-Group Dummy & $\begin{array}{l}0.374^{* * *} \\
(0.055)\end{array}$ & $\begin{array}{l}0.295^{* * *} \\
(0.058)\end{array}$ & $\begin{array}{l}0.294^{* * *} \\
(0.059)\end{array}$ & $\begin{array}{l}0.139 * * \\
(0.069)\end{array}$ & $\begin{array}{l}0.237^{* * *} \\
(0.071)\end{array}$ & $\begin{array}{l}0.217^{* * *} \\
(0.074)\end{array}$ & $\begin{array}{c}0.087 \\
(0.088)\end{array}$ \\
\hline $\begin{array}{l}\text { Business-Group Dummy } \\
\times R \& D \text { Intensity }\end{array}$ & $\begin{array}{l}0.038^{* * *} \\
(0.015)\end{array}$ & $\begin{array}{c}0.017 \\
(0.016)\end{array}$ & $\begin{array}{c}0.017 \\
(0.016)\end{array}$ & $\begin{array}{c}0.003 \\
(0.016)\end{array}$ & $\begin{array}{c}0.021 \\
(0.016)\end{array}$ & $\begin{array}{c}0.020 \\
(0.016)\end{array}$ & $\begin{array}{c}0.010 \\
(0.016)\end{array}$ \\
\hline $\begin{array}{l}\text { Business-Group Dummy } \\
\times \text { External Dependence }\end{array}$ & & $\begin{array}{l}0.087^{* * *} \\
(0.034)\end{array}$ & $\begin{array}{l}0.088^{* * *} \\
(0.035)\end{array}$ & $\begin{array}{l}0.099^{* * *} \\
(0.037)\end{array}$ & $\begin{array}{l}0.078^{* *} \\
(0.033)\end{array}$ & $\begin{array}{l}0.088^{* * *} \\
(0.034)\end{array}$ & $\begin{array}{l}0.082^{* *} \\
(0.038)\end{array}$ \\
\hline \multicolumn{8}{|l|}{$\begin{array}{l}\text { Business Group Dummy } \\
\text { interacted with: }\end{array}$} \\
\hline$[\ln (\text { Total Assets })]_{t-1}$ & & & $\begin{array}{c}-0.001 \\
(0.009)\end{array}$ & $\begin{array}{c}-0.001 \\
(0.013)\end{array}$ & & $\begin{array}{r}-0.007 \\
(0.009)\end{array}$ & $\begin{array}{c}-0.007 \\
(0.012)\end{array}$ \\
\hline$[\ln (\text { Cash Flow })]_{t-1}$ & & & & $\begin{array}{r}0.014^{*} \\
(0.007)\end{array}$ & & & $\begin{array}{r}0.014^{*} \\
(0.008)\end{array}$ \\
\hline Return on Assets $_{t-1}$ & & & & $\begin{array}{r}-0.017^{*} \\
(0.010)\end{array}$ & & & $\begin{array}{l}-0.025^{* *} \\
(0.010)\end{array}$ \\
\hline In(Firm Age $)$ & & & & $\begin{array}{l}-0.058^{* * *} \\
(0.020)\end{array}$ & & & $\begin{array}{l}-0.067^{* * *} \\
(0.021)\end{array}$ \\
\hline$[\ln (\text { Total Assets })]_{t-1}$ & $\begin{array}{l}0.231^{* * *} \\
(0.015)\end{array}$ & $\begin{array}{l}0.231^{* * *} \\
(0.015)\end{array}$ & $\begin{array}{l}0.233^{* * *} \\
(0.019)\end{array}$ & $\begin{array}{l}0.314^{* * *} \\
(0.024)\end{array}$ & $\begin{array}{l}0.231^{* * *} \\
(0.015)\end{array}$ & $\begin{array}{l}0.247^{* * *} \\
(0.024)\end{array}$ & $\begin{array}{l}0.324^{* * *} \\
(0.029)\end{array}$ \\
\hline$[\ln (\text { Cash Flow })]_{t-1}$ & & & & $\begin{array}{c}-0.019 \\
(0.014)\end{array}$ & & & $\begin{array}{c}-0.027 \\
(0.019)\end{array}$ \\
\hline Return on Assets $_{t-1}$ & & & & $\begin{array}{r}-0.005 \\
(0.018)\end{array}$ & & & $\begin{array}{l}0.035 \\
(0.033)\end{array}$ \\
\hline In(Firm Age) & & & & $\begin{array}{c}-0.198^{* * *} \\
(0.034)\end{array}$ & & & $\begin{array}{c}-0.134^{* * *} \\
(0.045)\end{array}$ \\
\hline Pre-sample fixed effect & $\begin{array}{l}0.699^{* * *} \\
(0.107)\end{array}$ & $\begin{array}{l}0.702^{* * *} \\
(0.107)\end{array}$ & $\begin{array}{l}0.702^{* * *} \\
(0.107)\end{array}$ & $\begin{array}{l}0.853^{* * *} \\
(0.158)\end{array}$ & $\begin{array}{l}0.701^{* * *} \\
(0.107)\end{array}$ & $\begin{array}{l}0.700^{* * *} \\
(0.107)\end{array}$ & $\begin{array}{l}0.850^{* * *} \\
(0.159)\end{array}$ \\
\hline Three-digit SIC dummies (110) & Yes & Yes & Yes & Yes & Yes & Yes & Yes \\
\hline Log pseudo likelihood & $-34,451.4$ & $-34,443.5$ & $-34,443.5$ & $-23,356.4$ & $-34,444.1$ & $-34,442.7$ & $-23,342.9$ \\
\hline Observations & 68,144 & 68,144 & 68,144 & 48,123 & 68,144 & 68,144 & 48,123 \\
\hline
\end{tabular}

Notes. This table reports the results of negative binomial regressions that examine the effect of external dependence on patents (firm-year) for a sample of innovative firms. R\&D Intensity, External Finance Dependence and External Equity Dependence are computed as the average three-digit SIC level for the period 1995-2004 based on Compustat firms. R\&D intensity is the ratio between R\&D expenditures and sales. External Finance Dependence is the ratio between capital expenditures minus cash flow from operations and capital expenditures. External Equity Dependence is the net amount of equity issued over capital expenditures. Pre-sample fixed effect is the yearly average number of patents a firm had from 1978 until the first year it appeared in our sample. Country, industry, and year fixed effects are included in all regressions. Standard errors (in parentheses) are robust to arbitrary heteroskedasticity and allow for serial correlation through clustering by firm.

*Significant at $10 \%$; ** significant at $5 \%$; ${ }^{* * *}$ significant at $1 \%$.

$R \& D$ expenses. Yet $R \& D$ information is available for public firms. We collect R\&D data for public firms that belong to groups from Osiris (a database by BvDEP that provides detailed accounting information for public firms). We use the information for the consolidated accounts of these public firms as a proxy of the group R\&D expenditures. The estimation results of conditioning group patenting on R\&D stock are reported in columns 3 and 11 of Table 8 . The coefficient on R\&D stock is positive and highly significant, as expected. The positive effect of the group-unrelated diversification remains robust. This result indicates that unrelated diversification is positively associated not only with the level of innovation but also with the number of patents produced conditional on R\&D expenditures.

\subsection{Knowledge Spillovers}

We test the knowledge spillovers hypothesis by examining whether affiliates of the same group have a similar research focus and whether they tend to cite each other's patents. Both tests suggest that knowledge spillovers are unlikely to be the main driver of the group-innovation relation. First, the average measure of technological similarity (TEC) between a firm and other firms in its group is 0.024 . Although it is significantly higher than the average technological similarity between a firm and all firms outside its group 
Table 8 Group Diversification

\begin{tabular}{|c|c|c|c|c|c|c|c|c|c|c|c|c|c|}
\hline \multirow[b]{2}{*}{ Dependent variable: } & (1) & (2) & (3) & (4) & (5) & (6) & (7) & (8) & (9) & (10) & (11) & (12) & (13) \\
\hline & \multicolumn{9}{|c|}{ Group EPO Patents } & \multicolumn{4}{|c|}{ Group USPTO Patents } \\
\hline Groups: & All & All & All & All & $\begin{array}{l}\text { Single- } \\
\text { country }\end{array}$ & $\begin{array}{c}\text { Multi- } \\
\text { nationals }\end{array}$ & All & $\begin{array}{l}\text { Family- } \\
\text { held }\end{array}$ & $\begin{array}{l}\text { Widely } \\
\text { held }\end{array}$ & All & All & All & All \\
\hline Total Diversification & $\begin{array}{l}0.611^{* * *} \\
(0.062)\end{array}$ & & & & & & & & & & & & \\
\hline $\begin{array}{l}\text { Unrelated } \\
\quad \text { Diversification }\end{array}$ & & $\begin{array}{l}0.867^{* * *} \\
(0.070)\end{array}$ & $\begin{array}{l}0.567^{* * *} \\
(0.153)\end{array}$ & $\begin{array}{l}0.520^{* * *} \\
(0.072)\end{array}$ & $\begin{array}{l}0.457^{* * *} \\
(0.147)\end{array}$ & $\begin{array}{l}0.525^{* * *} \\
(0.086)\end{array}$ & $\begin{array}{l}0.890 * * * \\
(0.071)\end{array}$ & $\begin{array}{l}0.803^{* * *} \\
(0.179)\end{array}$ & $\begin{array}{l}0.904 * * * \\
(0.076)\end{array}$ & $\begin{array}{l}0.993^{* * *} \\
(0.138)\end{array}$ & $\begin{array}{l}1.248^{* * *} \\
(0.198)\end{array}$ & $\begin{array}{l}0.570^{* * *} \\
(0.169)\end{array}$ & $\begin{array}{l}0.916 * * * \\
(0.133)\end{array}$ \\
\hline Related Diversification & & $\begin{array}{c}0.002 \\
(0.047)\end{array}$ & $\begin{array}{l}-0.056 \\
(0.034)\end{array}$ & $\begin{array}{r}-0.076 \\
(0.053)\end{array}$ & $\begin{array}{l}-0.199 \\
(0.160)\end{array}$ & $\begin{array}{c}-0.023 \\
(0.042)\end{array}$ & $\begin{array}{c}-0.001 \\
(0.046)\end{array}$ & $\begin{array}{c}0.099 \\
(0.243)\end{array}$ & $\begin{array}{c}-0.014 \\
(0.046)\end{array}$ & $\begin{array}{c}0.302 \\
(0.235)\end{array}$ & $\begin{array}{c}-0.044 \\
(0.128)\end{array}$ & $\begin{array}{c}0.265 \\
(0.260)\end{array}$ & $\begin{array}{l}0.186 \\
(0.194)\end{array}$ \\
\hline$\left[\ln (\text { Group R\&D Stock) }]_{t-1}\right.$ & & & $\begin{array}{l}0.521^{* * *} \\
(0.013)\end{array}$ & & & & & & & & $\begin{array}{l}0.682^{* * *} \\
(0.015)\end{array}$ & & \\
\hline $\begin{array}{l}\text { Country Concentration } \\
\text { Index }\end{array}$ & & & & $\begin{array}{l}-3.185^{* * *} \\
(0.180)\end{array}$ & & & & & & & & $\begin{array}{l}-6.149^{* * *} \\
(0.357)\end{array}$ & \\
\hline Family Ownership & & & & & & & $\begin{array}{c}-0.082 \\
(0.092)\end{array}$ & & & & & & $\begin{array}{l}-1.176^{* * *} \\
(0.146)\end{array}$ \\
\hline$[\ln (\text { Group Total Sales })]_{t-1}$ & $\begin{array}{l}0.589^{* * *} \\
(0.022)\end{array}$ & $\begin{array}{l}0.609 * * * \\
(0.022)\end{array}$ & $\begin{array}{l}0.531^{* * * *} \\
(0.044)\end{array}$ & $\begin{array}{l}0.536^{* * *} \\
(0.023)\end{array}$ & $\begin{array}{l}0.472^{* * *} \\
(0.048)\end{array}$ & $\begin{array}{l}0.491^{* * *} \\
(0.024)\end{array}$ & $\begin{array}{l}0.597^{* * *} \\
(0.022)\end{array}$ & $\begin{array}{l}0.539 * * * \\
(0.057)\end{array}$ & $\begin{array}{l}0.611^{* * *} \\
(0.024)\end{array}$ & $\begin{array}{l}0.626^{* * *} \\
(0.038)\end{array}$ & $\begin{array}{l}0.244^{* * *} \\
(0.053)\end{array}$ & $\begin{array}{l}0.461^{* * * *} \\
(0.033)\end{array}$ & $\begin{array}{l}0.601^{* * *} \\
(0.036)\end{array}$ \\
\hline $\begin{array}{l}\text { Group pre-sample } \\
\text { mean }\end{array}$ & $\begin{array}{l}1.438^{* * *} \\
(0.310)\end{array}$ & $\begin{array}{l}1.481^{* * *} \\
(0.310)\end{array}$ & $\begin{array}{c}0.039 \\
(0.023)\end{array}$ & $\begin{array}{l}1.298^{* * *} \\
(0.284)\end{array}$ & $\begin{array}{l}8.013^{* * *} \\
(1.873)\end{array}$ & $\begin{array}{l}0.510^{* * *} \\
(0.170)\end{array}$ & $\begin{array}{l}1.376^{* * *} \\
(0.293)\end{array}$ & $\begin{array}{l}4.778 * * * \\
(1.072)\end{array}$ & $\begin{array}{l}1.084^{* * *} \\
(0.241)\end{array}$ & $\begin{array}{l}1.426^{* * *} \\
(0.217)\end{array}$ & $\begin{array}{l}0.157^{* * *} \\
(0.039)\end{array}$ & $\begin{array}{l}1.125^{* * *} \\
(0.168)\end{array}$ & $\begin{array}{l}1.273^{* * *} \\
(0.197)\end{array}$ \\
\hline $\begin{array}{l}\text { Log pseudo } \\
\text { likelihood }\end{array}$ & $-51,872.3$ & $-51,625.0$ & $-8,819.5$ & $-50,716.2$ & $-12,782.9$ & $-35,998.0$ & $0-49,529.3$ & $-7,946.9$ & $-41,271.4$ & $-67,955.0$ & $-18,478.5$ & $-65,877.9$ & $-65,744.9$ \\
\hline Observations & 298,319 & 298,319 & 236,640 & 298,319 & 221,211 & 77,108 & 273,951 & 72,851 & 201,100 & 298,319 & 236,640 & 298,319 & 273,951 \\
\hline
\end{tabular}

Notes. This table reports the results of regressions that examine the relation between group diversification and innovation. The dependent variable is the yearly number of group patents (aggregated over group affiliates) for the period 1995-2004. Total Diversification, Unrelated Diversification, and Related Diversification are the Entropy measures developed in Palepu (1985) computed over the period 1995-2004. Country Concentration Index is the Herfindahl-Hirschman Index of concentration for the distribution of group sales across countries computed over the period 1995-2004. A group is a "single country" if all of its affiliates are located in one country. Group R\&D is based on the group public affiliates. R\&D stock is computed using the perpetual inventory method with a depreciation rate of $15 \%$. Following the "pre-sample mean scaling approach" of Blundell et al. (1999), our pre-sample control is the average number of patents a business group had until the first year it appeared in our sample. Standard errors (in parentheses) are robust to arbitrary heteroskedasticity and allow for serial correlation through clustering by group.

*Significant at $10 \% ;{ }^{* *}$ significant at $5 \% ;{ }^{* * *}$ significant at $1 \%$.

(0.014), it is very close to zero. Second, only $1 \%$ of the citations made by group affiliates are directed to other affiliates of the same group.

\subsection{Alternative Hypotheses}

4.4.1. Multinationals. Multinationals can differ from domestic firms on several dimensions. For example, Bloom et al. (2007) show that firms that are affiliated with multinational organizations are more likely to invest in "soft" innovation such as information communication technologies. If multinationals are also better in patenting than domiciles, the group dummy may be capturing this effect. Furthermore, affiliation to a multinational group may facilitate innovation by enhancing access to foreign technologies.

Columns $4-6$ and 12 of Table 8 summarize the estimation results. We test the multinationals hypothesis by examining whether groups that concentrate their sales in only few countries are less innovative than groups that spread their sales across many countries. We use the Herfindahl-Hirschman index (HHI) to measure group sales concentration across countries over the period 1995-2004 (a higher HHI means that the group sales are more concentrated across countries). According to the multinationals hypothesis, we expect a negative relation between $\mathrm{HHI}$ and group patents. A total of 49,237 groups in our sample are single-country (i.e., the HHI measure is one), and 12,506 groups include affiliates from more than one country. We find a negative and significant coefficient on the country HHI $(-3.185$ with a standard error of 0.180 for EPO patents, and -6.149 with a standard error of 0.357 for USPTO patents), implying a positive relation between multinationals and innovation. Importantly, the positive relation between group patents and unrelated diversification remains robust.

4.4.2. Quality of Governance in Family-Held Firms. The difference in innovation between standalones and affiliates can be explained by family ownership. On one hand, a family CEO may focus more on long-term compared to an unrelated chief executive. This may imply that family firms invest more in R\&D. However, a family CEO may have less expertise in innovation compared with a professional CEO. If family groups systematically differ from widely held groups in their diversification strategies, 
the diversification-innovation relation may be biased. Twenty-seven percent of the groups in our sample are family owned. Family groups are more specialized than widely held groups (for family groups the total diversification entropy measure is 0.402 , as compared to 0.480 for widely held groups). If family ownership is negatively related to innovation, the coefficient estimate on group diversification will be upward-biased. We test the family ownership hypothesis by including a dummy for family-owned groups. The estimation results are reported in columns 7-9 and 13 of Table 8 . The coefficient on family ownership is negative but not significant in the EPO patents regressions $(-0.082$ with a standard error of 0.092$)$. Family groups appear to be significantly less innovative than widely held groups in terms of USPTO patents $(-1.176$ with a standard error of 0.146). In all specifications, the coefficient on unrelated diversification remains robust.

\section{Discussion}

Our findings suggest that business groups foster innovation via internal capital markets. This result is especially interesting in light of the inefficiencies found in the internal capital market of U.S. conglomerates (Seru 2006, Robinson 2008). These inefficiencies are generally attributed to an ex-post commitment problem, where the headquarters cannot commit not to transfer funds from one division to the other. The intuition is that the headquarters rejects novel projects because it will not be able to evaluate the project and optimally decide whether to shut it down or continue with its funding. Why would the business-group internal capital market be more efficient for innovation than the conglomerate internal capital market? There are several possible leads. First, the business group structure is likely to mitigate the conglomerate commitment problem. The ultimate owner of a business group cannot shift funds from one company to the other at no cost because she would be expropriating the rights of the minority shareholders. ${ }^{11,12}$ Second, the legal boundaries between different members of the business group enable the group members to sign enforceable contracts with each other. Specifically, this allows business groups to utilize their internal capital markets via intragroup lending contracts.

\footnotetext{
${ }^{11}$ Even if in some cases the diversion of funds between two firms in the same group is legal, there is a cost associated with such action (Almeida and Wolfenzon 2006). For example, there is a waste involved in the diversion when the ultimate owner tries to shift the funds in sophisticated ways so the minority shareholders would not notice it.

${ }^{12}$ Conglomerates can try to mimic this structure by decentralizing their budget. Indeed, Seru (2006) reports that conglomerates that decentralized their budget to the divisions are able to mitigate some of the internal capital market inefficiencies.
}

Third, unlike conglomerate divisions, the earnings of business units are not consolidated, and ownership of intellectual property remains with the innovating affiliate. This implies that division managers can be incentivized as in VC-backed standalones based on the retained earnings.

\section{Conclusion}

Motivated by the mixed theoretical predictions and empirical findings on the relationship between organizational form and innovation, we investigate whether business groups foster innovation in Europe. Using a novel and comprehensive data set including ownership structures, financials, and patents, we find that group affiliates patent more than standalones or affiliates of small groups, controlling for size and other observable characteristics. We examine several hypotheses to explain this finding, focusing on group internal capital markets and knowledge spillovers. Our evidence is consistent with the group internal capital markets hypothesis. We find that the groupinnovation relation is stronger in industries that rely more on external finance and in groups with morediversified capital sources. For knowledge spillovers, we find that affiliates of the same group tend to have different research focus and are unlikely to cite each other's patents.

Our findings contribute to the debate on the relation between organizational structure and innovation. Recent evidence from the United States suggests that American conglomerates hinder innovation by encouraging poorly performing investments. Future research can further explore how the structural and legal differences between conglomerates and business groups lead to an adverse relation with respect to innovation. A promising starting point would be to focus on differences between Europe and the United States. Whereas European firms can liberally choose the corporate form that is most conducive to their R\&D effort, tax and regulatory hurdles in the United States essentially eliminate potential gains of maintaining a business group. Comparing the scale and novelty of innovation across different ownership structures and industries in these countries can shed more light on the complex relation between organizational form and innovation.

\section{Acknowledgments}

The authors express special gratitude to Patrick Bolton, Francisco Perez-Gonzalez, Mark Schankerman, and John Van Reenen for numerous helpful discussions. The authors are also grateful for valuable comments from Nick Bloom, Steve Bond, Bjorn Jorgensen, Tarun Khanna, Josh Lerner, Will Mitchell, Daniel Paravisini, Tano Santos, 
Scott Stern, Catherine Thomas, Manuel Trajtenberg, Daniel Wolfenzon, Yishay Yafeh, and three anonymous referees. The authors thank Liat Oren for invaluable assistance with the programming of the ownership algorithm, Hadar Gafni for excellent research assistance, and the Institute for Fiscal Studies, especially Rachel Griffith and Gareth Macartney, for the EPO patent matching. All remaining errors are the authors'.

\section{Appendix}

\section{A. Determining Business-Group Affiliation}

This section details the construction and output of our newly developed algorithm. The purpose of the algorithm is to determine the structure of European business groups based on the Amadeus ownership database. We complement the Amadeus data with ownership data for American firms (private and public) from Icarus. There are approximately 1 million ownership links that satisfy our control assumptions (50\% of private firms and 20\% public firms). Approximately 150,000 links include American subsidiaries. The algorithm consists of two parts: a control-chain generator that constructs the ownership and control links between different European firms, and a name-matching procedure that groups firms that are controlled by the same ultimate owner.

\section{A.1. Control-Chain Generator}

The algorithm follows three steps: (i) completes missing ownership links, (ii) generates lists of all subsidiaries and parents for each company, and (iii) constructs the ownership chains bottom-up. ${ }^{13}$ To illustrate our methodology, it would be useful to consider the following example. Suppose Figure A.1 correctly describes the ownership structure of a business group. The ultimate owner (e.g., a family) at the apex of the group controls seven public and private firms. Amadeus provides detailed data on direct ownership links. Thus, our raw data include the links $A \rightarrow D, B \rightarrow F$, $C \rightarrow G$, and $D \rightarrow E$. Note that the percentage of ownership for the link $C \rightarrow G$ has to be larger than 20 (because firm $G$ is public), where for the percentage of ownership for all other links has to be larger than 50 (because the other subsidiaries are private). Because there is no information about indirect ownership links, the link $\mathrm{A} \rightarrow \mathrm{E}$ is missing from the raw data. The first step of the algorithm is to complete missing links. As we observe the ownership relations $A \rightarrow D$ and $\mathrm{D} \rightarrow \mathrm{E}$, our algorithm infers the ownership relation $\mathrm{A} \rightarrow \mathrm{E}$. Note that at this stage of the algorithm we still do not know whether the ownership relation is direct or indirect (and, if it is indirect, how many layers separate firm E from firm A). The second step of the algorithm is to construct two lists for each firm: shareholders and subsidiaries. This step

\footnotetext{
${ }^{13}$ Unlike business groups in East Asia (such as the Japanese keiretsu), most European business groups are organized in pyramids (Figure A.1). This means that interlocking shareholdings are not common and, therefore, ownership chains can be constructed bottom-up.
}

Figure A.1 Example of a Business Group

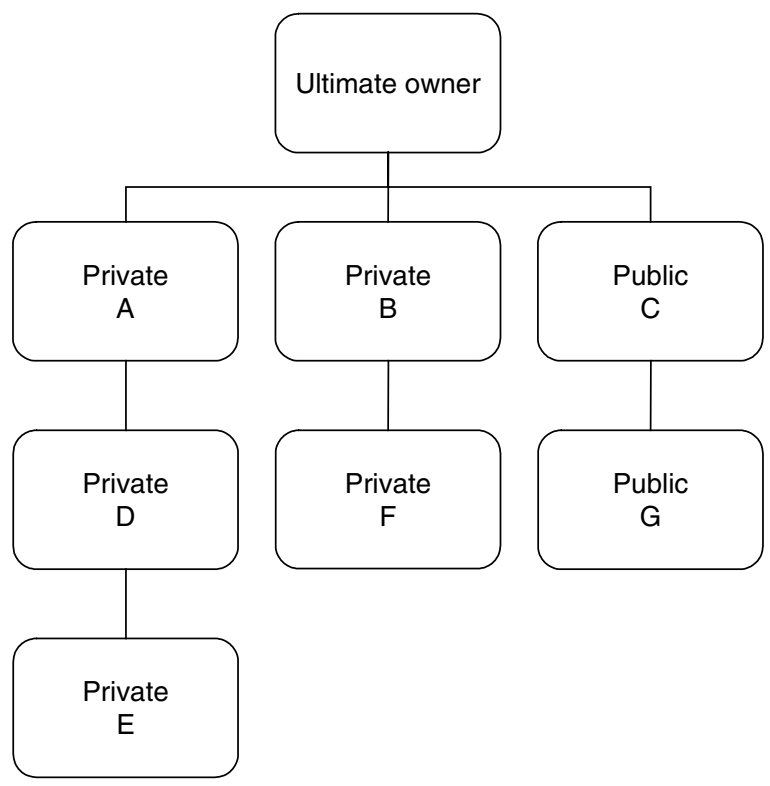

saves valuable running time, which is especially important when dealing with large-scale ownership data. The following table is generated:

\begin{tabular}{lcc}
\hline Firm & Shareholder & Subsidiary \\
\hline A & - & D, E \\
B & - & F \\
C & - & G \\
D & A & E \\
E & A, D & - \\
F & B & - \\
G & C & - \\
\hline
\end{tabular}

Note that from step 1 we already know that firm $A$ is a shareholder of firm E. Also, because we assume that the ultimate owner is a family, firms $\mathrm{A}, \mathrm{B}$, and $\mathrm{C}$ have no corporate (European) shareholder. The third and final step of the algorithm is to construct the structure of the group based on the above ownership relations. Because of the missing links problem, our algorithm does not assume that an ownership relation is direct; the only input that the algorithm receives is the existence of the ownership relation. We start with a firm that has no subsidiaries from the list generated in step 2. We illustrate the procedure for firm E, which is the most interesting in this example. Firm E is placed at the bottom of the ownership chain. Next we move to the shareholder list of firm E. It includes firms A and D. Starting arbitrarily with A, place A above E. Proceeding to firm D, there are three possibilities for its location: (i) D is above $\mathrm{E}$ and above A, (ii) D is above E but below A, (iii) D is above E but not below or above A (different ownership chain). For (i) to be the right structure, D has to appear in the shareholder list of firm A. From step 2, we rule this out. For (ii) to be the right structure, $\mathrm{D}$ has to appear on the subsidiary list of firm A. From step 2, this holds. Finally, for (iii) to be the right structure, A cannot appear on either the shareholder 
or subsidiary lists of firm D. From step 2, this is ruled out. At the end of this procedure, we have determined for each ownership chain the highest shareholder firm-we call this firm the leading shareholder.

The ordering procedure does not apply in the case of cross-holdings. For example, suppose that we also observe the ownership link $\mathrm{E} \rightarrow \mathrm{A}$. In this case, there is no starting point: no firm is placed at the bottom of the business group, and therefore the leading shareholder cannot be determined. ${ }^{14}$ Our algorithm flags these cases.

\section{A.2. Ultimate Owner Name Matching}

The next part of our algorithm groups firms across ownership chains based on the name of the ultimate owners. The name-matching process deals with two main issues. First, ultimate owner names are not standardized; i.e., the same name can be spelled differently across subsidiaries. Second, common names, especially for family members, may lead to "overgrouping." We deal with these issues as follows. First, we develop a name-standardization procedure that harmonizes the different string patterns in our data. Second, to ensure families are indeed wealthy, we search for publicly available information, such as Forbes and The Economist, on the largest 500 wealthiest families in our sample (e.g., the De Rotchild family, the Nasi-Agnelli family). For the other individual ultimate owners in our sample we compute the frequency of the appearance of the name in the ultimate owner population. If this frequency is higher than the median frequency, we assume the common name problem and do not include that ultimate owner in our sample. Our control assumptions may lead to cases where we misclassify firms to groups. For example, suppose that an ultimate owner controls $33 \%$ of firm $\mathrm{C}$, and firms $\mathrm{A}$ and $\mathrm{B}$ control each $33 \%$ of firm C. Assuming firm $\mathrm{C}$ is private, our algorithm will not assign firm $C$ to a group. The ultimate owner fully controls firm $C$ (via its control of firms $A$ and $B$ ); thus, firm $C$ should be part of the group. To deal with this situation we take the following step. For firms that were not assigned to groups we extract a list of their immediate shareholders (corporate and individuals). For each shareholder we already know whether it belongs to a group and its ultimate owner (as indicated by the ownership algorithm). Then we examine whether an ultimate owner controls $>50 \%$ of the stocks for private firms and $>20 \%$ of the stocks for public firms. If the aggregated holding of the ultimate owner meets these thresholds, we assign the affiliate to the group.

Finally, our control assumptions may lead to multiple assignments of ultimate owners. A total of 2,064 affiliates are subject to multiple holding, of which only 11 firms innovate and 18 are public. If our algorithm identifies two groups for the same affiliate, we assign two different ultimate owners for this affiliate.

\footnotetext{
${ }^{14}$ A less "severe" case of cross-holding is where we observe $\mathrm{E} \rightarrow \mathrm{D}$. In this case, our algorithm constructs two ownership chains: $A \rightarrow$ $\mathrm{D} \rightarrow \mathrm{E}$ and $\mathrm{A} \rightarrow \mathrm{D} \rightarrow \mathrm{E}$, where both correctly characterize the ownership structure. The leading shareholder is firm A in both cases, which allows us to correctly group firms into groups.
}

\section{A.2. Matching Patent Data}

\section{A.2.1. European Patent Office}

The matching between EPO patent applicants and Amadeus firms has been a collaborative project with the Institute for Fiscal Studies (IFS) and the Centre for Economic Performance (CEP). This section is a brief summary of the matching procedure.

Our main information source on patents is the 2005 publication of the PATSTAT database, which is the standard source for European patent data. This database contains all bibliographic data (including citations) on all European patent applications and granted patents, from the beginning of the EPO system in 1978 to the end of 2004.

We match the name of each EPO applicant listed on the patent document to the full name of a firm listed in Amadeus (approximately 8 million names). Because we are interested only in matching patent applicants to firms, we exclude applicant names that fall into the following categories: government agencies, universities, and individuals. We identify government agencies and universities by searching for a set of identifying strings in their name. We identify individuals as patents where the assignee and the inventor name strings are identical.

The matching procedure follows two main steps. (i) Standardizing names of patent applicants. This involves replacing commonly used strings that symbolize the same thing, for example "Ltd." and "Limited" in the United Kingdom. We remove spaces between characters and transform all letters to capital letters. As an example, the name "British Nuclear Fuels Public Limited Company" becomes "BRITISHNUCLEARFUELSPLC." (ii) Name matching: Match the standard names of the patent applicants with Amadeus firms. If there is no match, then try to match to the old firm name available in Amadeus. We need to confront a number of issues. First, in any given year the Amadeus database excludes the names of firms that have not filed financial reports for four consecutive years (e.g., M\&A, default). We deal with this issue in several ways. First, we use information from historical versions of the Amadeus database (1995-2003) on names and name changes. Second, even though Amadeus contains a unique firm identifier (BvD ID number), there are cases in which firms with identical names have different BvDEP numbers. In these cases, we use other variables for identification, e.g., address (ZIP code), date of incorporation (whether consistent with the patent application date), and more. Finally, we manually match most of the remaining corporate patents to the list of Amadeus firms.

Some groups assign many of their patents to a single subsidiary. This subsidiary typically does not innovate, and its main purpose is to manage the intellectual property assets of the group. We identify such firms using their SIC classification. We use information on the location of the patent inventors to match the centrally assigned patents to innovative affiliates. The secondary assignment of these patents is based on a match between the address of the patent inventor and the group affiliates. If the address of the inventor matches multiple group affiliates we make the following assumption: if only one of the affiliates innovates (as indicated by the number of patents this affiliate already has), 
assign the patent to this innovative affiliate. If more than one of the matched affiliates innovates, keep the original central assignment of the patent. The secondary matching procedure increases the number of innovative affiliates by approximately 250 firms.

\section{A.2.2. United States Patent and Trademark Office}

The procedure described above matches European firms to patents registered with the EPO. Yet some European firms register patents only with the USPTO, without applying to the EPO. To identify the European firms that apply only to the USPTO, we match the complete set of Amadeus firms to the names of the patent applicants from the USPTO. The most updated patent database for the USPTO is the 2002 version of the NBER patents and citations data archive. Because this database covers patent information only up to 2002 and our accounting data go up to 2004, we updated the patent data file by extracting all information about patents granted between 2002 and 2004 directly from the USPTO website. ${ }^{15}$ Having updated the USPTO patent database, we follow the matching procedure described above to create the matched USPTO patent data for the Amadeus firms.

\section{A.3. Accounting Database}

The accounting information is taken from Amadeus. The database contains financial information on approximately 8 million firms from 34 countries, including all of the European Union countries and Eastern Europe. The accounts of each firm are followed for up to ten years. The information source for Amadeus is approximately 50 country vendors (generally the office of register of Companies). The main advantage of Amadeus over other data sources is its coverage of small and medium-size firms.

The accounting database includes items from the balance sheet (22 items) and income statement (22 items). No information is available from the changes in cash flow report (i.e., investment data are not available). The accounting data are harmonized by BvDEP to enhance comparison across countries. This comparison becomes easier over time because of the improvement in the European Union harmonization is accounting standards. In addition to accounting data items, Amadeus provides a description of firms including their product market activity. The main descriptive items are legal form (public versus private), date of incorporation, types of accounts (consolidated versus unconsolidated), country, and U.S. SIC and NAIC codes for the product market activity of the firm (primary and nonprimary). The industry location information includes up to eight different six-digit NAIC codes per firm (note that the sales of the firm are not broken up across the different product markets).

An important feature of the data is the criteria for dropping firms from the sample over time. As long as a firm continues to file its financial statements, it continues to appear in Amadeus. If a firm becomes inactive, it stops filing its financial statement (alternatively, a firm can be late in filing its financial statement). This firm will be kept in the sample for four extra years since the last year financial statements were reported (thus, in the fifth year the

${ }^{15}$ http://patft.uspto.gov/netahtml/PTO/srchnum.htm. firm will be removed from the sample). For example, a firm that becomes inactive and stops filing its reports in 1995 (i.e., 1994 is the last year when a financial statement was reported) will remain in the database until 1998 (including), and in 1999 it will be dropped from the sample (all observations of the specific firm will be taken out of the Amadeus database in the 1999 update). To mitigate the problem of losing dead firms, we purchased old Amadeus disks that allow tracking firms that exit the sample in previous years. For example, the firm that exits in 1995 will appear in the 1998 Amadeus disk but not in the 1999 disk. By using both 1998 and 1999 disks, we mitigate the selection bias of dropping inactive firms after four years of missing data.

\section{A.4. Constructing Industry Variables}

We construct the industry measures used in the econometric specifications using data from Compustat and Amadeus. The following variables are based on Compustat. They are a weighted average over the period 1980-2004 and are computed at the three-digit U.S. SIC level. External Finance Dependence: this variable is defined as the ratio of Capital Expenditures (Compustat 128) minus Cash Flow (110) to Capital Expenditures. When 110 is missing, Cash Flow is defined as the sum of the following Compustat items: 123, 125, 126, 106, 213, and 217. External Equity Dependence: this variable is defined as the ratio of the net amount of equity issued (108 minus 115) to capital expenditures. R\&D (XRD) data are taken from OSIRIS and are used to create R\&D capital stocks calculated using a perpetual inventory method with a $15 \%$ depreciation rate (Hall et al. 2005).

\section{References}

Almeida, H., D. Wolfenzon. 2006. A theory of pyramidal ownership and family business groups. J. Finance 61(6) 2637-2680.

Arrow, K. 1962. Economic welfare and the allocation of resources of inventions. R. Nelson, ed. The Rate and Direction of Inventive Activity: Economic and Social Factors. Princeton University Press, Princeton, NJ, 609-626.

Bloom, N., R. Sadun, J. Van Reenen. 2007. Americans do I.T. better: US multinationals and the productivity miracle. Working paper, London School of Economics, London.

Blundell, R., R. Griffith, J. Van Reenen. 1999. Market share, market value and innovation in a panel of British manufacturing firms. Rev. Econom. Stud. 66(3) 529-554.

Cadbury, A. 2000. Family Firms and Their Governance: Creating Tomorrow's Company from Today's. Egon Zehnder International, London.

Chang, S.-J., C.-N. Chang, I. Mahmood. 2006. When and how does business group affiliation promote firm innovation? A tale of two emerging economies. Organ. Sci. 17(5) 637-656.

Cohen, W., S. Klepper. 1996. A reprise of size and R\&D. Econom. J. 106(437) 925-951.

Cohen, W., R. C. Levin. 1989. Empirical studies of innovation and market structure. R. Schmalensee, R. Willig, eds. Handbook of Industrial Organization, Vol. II. Elsevier, Oxford, UK, 1059-1107.

Duchin, R. 2010. Cash holdings and corporate diversification. J. Finance. Forthcoming.

Faccio, M., L. Lang. 2002. The ultimate ownership of Western European corporations. J. Financial Econom. 65(3) 365-395.

Greenwald, B., J. E. Stiglitz, A. Weiss. 1984. Informational imperfections in the capital markets and macro-economic fluctuations. Amer. Econom. Rev. 74(1) 194-199. 
Griffith, R., R. Harrison, J. Van Reenen. 2006. How special is the special relationship? Using the impact of U.S. R\&D spillovers on U.K. firms as a test of technology sourcing. Amer. Econom. Rev. 96(5) 1859-1875.

Griliches, Z. 1979. Issues in assessing the contribution of research and development to productivity growth. Bell J. Econom. 10(1) 92-116.

Griliches, Z. 1990. Patent statistics as economic indicators: A survey. J. Econom. Literature 28(4) 1661-1707.

Hall, B., A. Jaffe, M. Trajtenberg. 2001. The NBER patent citations data file: Lessons, insights and methodological tools. NBER Working Paper 8498, National Bureau of Economic Research, Cambridge, MA.

Hall, B., A. Jaffe, M. Trajtenberg. 2005. Market value and patent citations. RAND J. Econom. 36(1) 16-38.

Hausman, J., B. Hall, Z. Griliches. 1984. Econometric models for count data with an application to the patents-R\&D relationship. Econometrica 52(4) 909-938.

Himmelberg, C., B. Petersen. 1994. R\&D and internal finance: A panel study of small firms in high-tech industries. Rev. Econom. Statist. 76(1) 38-51.

Hitt, M., R. Hoskisson, R. Johnson, D. Moesel. 1996. The market for corporate control and firm innovation. Acad. Management J. 39(5) 1084-1119.

Jaffe, A. 1986. Technological opportunity and spillovers of R\&D: Evidence from firms' patents, profits and market value. Amer. Econom. Rev. 76(5) 984-1001.

Jaffe, A., M. Trajtenberg. 2002. Patents, Citations and Innovations: A Window on the Knowledge Economy. MIT Press, Cambridge, MA.

Khanna, T., K. Palepu. 1999. The right way to restructure conglomerates in emerging markets. Harvard Bus. Rev. 77 125-134.
Khanna, T., J. Rivkin. 2001. Estimating the performance effects of business groups in emerging markets. Strategic Management J. 22(1) 45-74.

Khanna, T., Y. Yafeh. 2007. Business groups in emerging markets: Paragons or parasites? J. Econom. Literature 45(2) 331-372.

La Porta, R., F. Lopez-de-Silanes, A. Shleifer. 1999. Corporate ownership around the world. J. Finance 54(2) 471-517.

Mahmood, I.P., W. Mitchell. 2004. Two faces: Effects of business groups on innovation in emerging economies. Management Sci. 50(10) 1348-1365.

Morck, R. 2005. How to eliminate pyramidal business groups: The double-taxation of intercorporate dividends and other incisive uses of tax policy. Tax Policy Econom. 19 135-179.

Myers, S., N. S. Majluf. 1984. Corporate financing and investment decisions when firms have information that investors do not have. J. Financial Econom. 13(2) 187-221.

Nelson, R. 1959. The simple economics of basic scientific research. J. Political Econom. 67 297-306.

Palepu, K. 1985. Diversification strategy, profit performance and the entropy measure. Strategic Management J. 6(3) 239-255.

Rajan, R., L. Zingales. 1998. Financial dependence and growth. Amer. Econom. Rev. 88(3) 559-586.

Reinganum, J. 1983. Uncertain innovation and the persistence of monopoly. Amer. Econom. Rev. 73(4) 61-66.

Scherer, F. M. 1982. Inter-industry technology flows in the United States. Res. Policy 11(4) 227-245.

Seru, A. 2006. Do conglomerates stifle innovation? Working paper, University of Chicago, Chicago.

Stein, J. 1997. Internal capital markets and the competition for corporate resources. J. Finance 52(1) 111-133.

Teece, D. 1996. Firm organization, industrial structure, and technological innovation. J. Econom. Behav. Organ. 31(2) 193-224. 